\title{
An SEM, EDS and vibrational spectroscopic study of the silicate mineral meliphanite $(\mathrm{Ca}, \mathrm{Na})_{2} \mathrm{Be}\left[(\mathrm{Si}, \mathrm{Al})_{2} \mathrm{O}_{6}(\mathrm{~F}, \mathrm{OH})\right]$
}

\author{
Ray L. Frost ${ }^{\mathrm{a}, *}$, Andrés López ${ }^{\mathrm{a}}$, Frederick L. Theiss ${ }^{\mathrm{a}}$, Antônio Wilson Romano ${ }^{\mathrm{b}}$, Ricardo Scholz ${ }^{\mathrm{b}}$

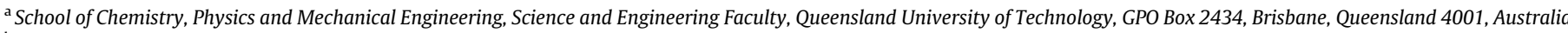 \\ ${ }^{\mathrm{b}}$ Geology Department, School of Mines, Federal University of Ouro Preto, Campus Morro do Cruzeiro, Ouro Preto, MG 35400-00, Brazil
}

\section{H I G H L I G H T S}

\section{- Meliphanite}

$(\mathrm{Ca}, \mathrm{Na})_{2} \mathrm{Be}\left[(\mathrm{Si}, \mathrm{Al})_{2} \mathrm{O}_{6}(\mathrm{~F}, \mathrm{OH})\right]$ is a crystalline sodium calcium beryllium silicate.

- The mineral was characterized by scanning electron microscopy (SEM) with energy dispersive spectroscopy (EDX).

- EDX analysis shows high concentrations of $\mathrm{Si}$ and $\mathrm{Ca}$ and low amounts of $\mathrm{Na}, \mathrm{Al}$ and $\mathrm{F}$.

- Raman spectroscopy identifies bands in the $\mathrm{OH}$ stretching region.

\section{A R T I C L E I N F O}

\section{Article history:}

Received 8 July 2014

Received in revised form 24 August 2014

Accepted 11 September 2014

Available online 2 October 2014

\section{Keywords}

Meliphanite

Melitite

Leucophanite

Raman spectroscopy

Infrared spectroscopy

\section{G R A P H I C A L A B S T R A C T}

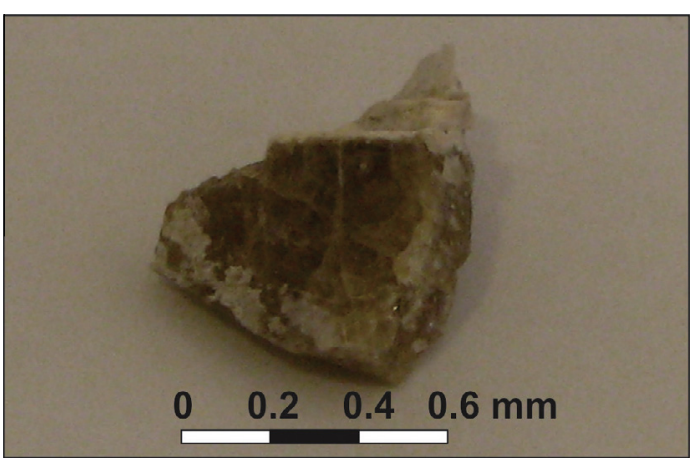

\begin{abstract}
A B S T R A C T
The mineral meliphanite $(\mathrm{Ca}, \mathrm{Na})_{2} \mathrm{Be}\left[(\mathrm{Si}, \mathrm{Al})_{2} \mathrm{O}_{6}(\mathrm{~F}, \mathrm{OH})\right]$ is a crystalline sodium calcium beryllium silicate which has the potential to be used as piezoelectric material and for other ferroelectric applications. The mineral has been characterized by a combination of scanning electron microscopy (SEM) with energy dispersive spectroscopy (EDS) and vibrational spectroscopy. EDS analysis shows a material with high concentrations of $\mathrm{Si}$ and $\mathrm{Ca}$ and low amounts of $\mathrm{Na}, \mathrm{Al}$ and $\mathrm{F}$. Beryllium was not detected. Raman bands at 1016 and $1050 \mathrm{~cm}^{-1}$ are assigned to the $\mathrm{SiO}$ and $\mathrm{AlOH}$ stretching vibrations of three dimensional siloxane units. The infrared spectrum of meliphanite is very broad in comparison with the Raman spectrum. Raman bands at 472 and $510 \mathrm{~cm}^{-1}$ are assigned to OSiO bending modes. Raman spectroscopy identifies bands in the $\mathrm{OH}$ stretching region. Raman spectroscopy with complimentary infrared spectroscopy enables the characterization of the silicate mineral meliphanite.
\end{abstract}

(c) 2014 Elsevier B.V. All rights reserved.

\section{Introduction}

The mineral meliphanite has the formula $(\mathrm{Ca}, \mathrm{Na})_{2} \mathrm{Be}\left[(\mathrm{Si}, \mathrm{Al})_{2}-\right.$ $\left.\mathrm{O}_{6}(\mathrm{~F}, \mathrm{OH})\right][1]$. The mineral was discovered in 1852 and is named after the Greek word for honey because of the honey like colour of the mineral. Please see the picture of the meliphanite mineral used in the graphical abstract. Considerable variation in colour

\footnotetext{
* Corresponding author. Tel.: +61 73138 2407; fax: +61 731381804 .

E-mail address: r.frost@qut.edu.au (R.L. Frost).
}

may be observed among samples of meliphanite from orange to black. The mineral is known from several places worldwide [2-4] and is often collected as a semi-precious jewel (please see http:// www.gemsociety.org/article/meliphanite-jewelry-and-gemstoneinformation/). It should be noted that there are a range of formulae which are given for meliphanite including $\left[(\mathrm{Ca}, \mathrm{Na})_{2} \mathrm{Be}(\mathrm{Si}, \mathrm{Al})_{2}\right.$ $\left.(\mathrm{O}, \mathrm{OH}, \mathrm{F})_{7}\right], \mathrm{Ca}(\mathrm{Na}, \mathrm{Ca}) \mathrm{BeSi}_{2} \mathrm{O}_{6} \mathrm{~F},(\mathrm{Ca}, \mathrm{Na})_{2} \mathrm{Be}\left[(\mathrm{Si}, \mathrm{Al})_{2} \mathrm{O}_{6}(\mathrm{~F}, \mathrm{OH})\right]$ and $\mathrm{Ca}_{4}(\mathrm{Na}, \mathrm{Ca})_{4} \mathrm{Be}_{4} \mathrm{AlSi}_{7} \mathrm{O}_{24}(\mathrm{~F}, \mathrm{O})_{4}$ [5]. It is apparent that the exact formula of the mineral remains to be precisely determined and of course, it may vary according to the sample origin. It is apparent 
that some of the physical properties of the mineral meliphanite remain to be measured.

The mineral is tetragonal with space group $I 4$ bar and $Z=8$ [1]. The cell dimensions are $a=10.5257(3) \AA, c=9.8868(4) \AA$, $V=1095.37(8) \AA^{3}$. The crystal structure was solved by comparison with the silicate mineral melitite [1]. The crystal structure consists of infinite sheets of $\mathrm{SiO}_{4}$ and $\mathrm{BeO}_{4}$ tetrahedra between which $\mathrm{Ca}$ or $(\mathrm{Ca}, \mathrm{Na})$ are sandwiched. The coordination polyhedra of these cations are distorted trigonal prisms. Grice and Hawthorne [5] refined the structure of meliphanite and state that the anomalous biaxial character of tetragonal meliphanite is likely due to stress within the crystal structure as a result of twinning. The presence of aluminium in the tetrahedra layers enables the distinction between meliphanite and leucophanite, $\mathrm{Ca}_{4} \mathrm{Na}_{4} \mathrm{Be}_{4} \mathrm{Si}_{8} \mathrm{O}_{24} \mathrm{~F}_{4}$ [6]. These two minerals are noted for their fluorescent properties [7] (see http:// www.csiro.au/luminescence/Default.aspx). Gugiaite $\mathrm{Ca}_{2} \mathrm{BeSi}_{2} \mathrm{O}_{7}$ is a melitite mineral and is named for the Chinese village of Gugia where it was first discovered [8]. It occurs mostly in skarns with melanite adjacent to an alkali syenite. Shortly after the discovery of gugiaite, it was noted that a new name was unnecessary as it could have been considered an end member of meliphanite differing mainly in containing much less $\mathrm{Na}$ and F. Recent data have confirmed that gugiaite does differ from meliphanite optically and structurally [5]. Gugiaite is a melilite and is distinctly different from other beryllium minerals such as meliphanite and leucophanite [5]. These beryllium bearing minerals are strongly piezoelectric.

No Raman spectroscopic studies of meliphanite and related minerals have been forthcoming [9]. Some infrared studies of selected calcium silicates have been undertaken $[10,11]$. Few studies have been made on beryllium containing silicates. Studies of hydrogen bonding in silicates relates the position of the hydroxyl stretching vibration to the hydrogen bond distances [12]. Some discussion in the literature relates to the presence of $\mathrm{OH}$ groups in the structure of meliphanite [5]. Some Raman spectra of calcium silicates have been collected and a number of the spectra were shown to be dependent upon the number of condensed silica tetrahedra [13]. Such detailed assignment of infrared and Raman bands for a wide range of silicate structures was made by Dowty [14-17]. The thermal decomposition of calcium silicates has also been measured [18-20].

There is an apparent lack of information on the vibrational spectra of meliphanite. The reason for such a lack of information is not known; yet the mineral contains siloxane units. Such units lend themselves to vibrational spectroscopy. Raman spectroscopy has proven most useful for the study of mineral structure [21-24]. The objective of this research is to report the Raman and infrared spectra of meliphanite and to relate the spectra to the mineral structure.

\section{Experimental}

Samples description and preparation

The meliphanite sample studied in this work forms part of the collection of the Geology Department of the Federal University of Ouro Preto, Minas Gerais, Brazil, with sample code SAC-144. The mineral originated from from Østskogen larvikittbrudd, Tvedalen (Tveidalen), Larvik kommune, Vestfold fylke, Norway. A detailed study of the locality was published [25].

The sample was gently crushed and the associated minerals were removed under a stereomicroscope Leica MZ4. The meliphanite studied in this work occurs in association with siderite. Scanning electron microscopy (SEM) in the EDS mode was applied to support the mineral characterization.

\section{Scanning electron microscopy (SEM)}

Experiments and analyses involving electron microscopy were performed in the Center of Microscopy of the Universidade Federal de Minas Gerais, Belo Horizonte, Minas Gerais, Brazil (http:// www.microscopia.ufmg.br).

Meliphanite crystals were coated with a $5 \mathrm{~nm}$ layer of evaporated carbon. Secondary Electron and Backscattering Electron images were obtained using a JEOL JSM-6360LV equipment. Qualitative and semi-quantitative chemical analyses in the EDS mode were performed with a ThermoNORAN spectrometer model Quest and was applied to support the mineral characterization. The same sample was used for SEM with EDS and vibrational spectroscopy.

\section{Raman microprobe spectroscopy}

Crystals of meliphanite were placed on a polished metal surface on the stage of an Olympus BHSM microscope, which is equipped with $10 \times, 20 \times$, and $50 \times$ objectives. The microscope is part of a Renishaw 1000 Raman microscope system, which also includes a monochromator, a filter system and a CCD detector (1024 pixels). The Raman spectra were excited by a Spectra-Physics model 127 He-Ne laser producing highly polarized light at $633 \mathrm{~nm}$ and collected at a nominal resolution of $2 \mathrm{~cm}^{-1}$ and a precision of $\pm 1 \mathrm{~cm}^{-1}$ in the range between 200 and $4000 \mathrm{~cm}^{-1}$. Repeated acquisitions on the crystals using the highest magnification $(50 \times)$ were accumulated to improve the signal to noise ratio of the spectra. Raman Spectra were calibrated using the $520.5 \mathrm{~cm}^{-1}$ line of a silicon wafer. The Raman spectrum of at least 10 crystals was collected to ensure the consistency of the spectra. An image of the meliphanite crystals measured is shown in the graphical abstract. Clearly the crystals of meliphanite are readily observed, making the vibrational spectroscopic measurements readily obtainable.

\section{Infrared spectroscopy}

Infrared spectra were obtained using a Nicolet Nexus 870 FTIR spectrometer with a smart endurance single bounce diamond ATR cell. Spectra over the $4000-525 \mathrm{~cm}^{-1}$ range were obtained by the co-addition of 128 scans with a resolution of $4 \mathrm{~cm}^{-1}$ and a mirror velocity of $0.6329 \mathrm{~cm} / \mathrm{s}$. Spectra were co-added to improve the signal to noise ratio.

Spectral manipulation such as baseline correction/adjustment and smoothing were performed using the Spectracalc software package GRAMS (Galactic Industries Corporation, NH, USA). Band component analysis was undertaken using the Jandel 'Peakfit' software package that enabled the type of fitting function to be selected and allows specific parameters to be fixed or varied accordingly. Band fitting was done using a Lorentzian-Gaussian cross-product function with the minimum number of component bands used for the fitting process. The Gaussian-Lorentzian ratio was maintained at values greater than 0.7 and fitting was undertaken until reproducible results were obtained with squared correlations of $r^{2}$ greater than 0.995 .

\section{Results and discussion}

\section{Chemical characterization}

The SEM image of meliphanite sample studied in this work is shown in Fig. 1. The image shows a cleavage fragment up to $2 \mathrm{~mm}$. Qualitative chemical analysis shows a homogeneous phase, composed by $\mathrm{Ca}, \mathrm{Na}, \mathrm{Al}$ and $\mathrm{Si}$. Minor amount of fluorine was also observed. No other contaminant elements were detected and the 


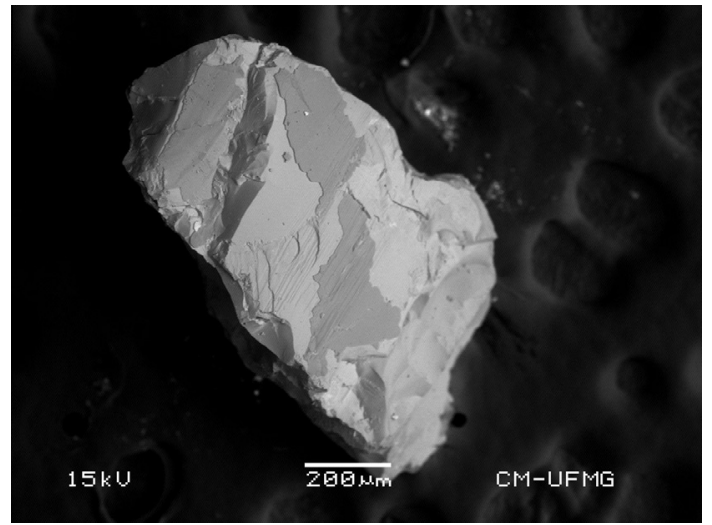

Fig. 1. Backscattered electron image (BSI) of a meliphanite crystal fragment up to $2.0 \mathrm{~mm}$ in length.

sample can be considered as a pure single phase (Fig. 2). No Be was determined because of its low atomic number.

\section{Vibrational spectroscopy}

The Raman spectrum of meliphanite over the $100-4000 \mathrm{~cm}^{-1}$ spectral range is shown in Fig. 3a. This figure shows the position and relative intensity of the Raman bands. It is noted there are large parts of the spectrum where little or no intensity is observed. The Raman spectrum is therefore subdivided into sections based upon the types of vibration being studied. It is noted that in the $\mathrm{OH}$ stretching region between 3000 and $3800 \mathrm{~cm}^{-1}$, considerable intensity is observed. The infrared spectrum of meliphanite over the $500-1500 \mathrm{~cm}^{-1}$ spectral range is displayed in Fig. $3 \mathrm{~b}$. This figure shows the position and relative intensities of the infrared bands. There is minimal intensity observed beyond $1500 \mathrm{~cm}^{-1}$. The infrared spectrum is subdivided into sections based upon the type of vibration being analysed.

The Raman spectrum of meliphanite over the $850-1150 \mathrm{~cm}^{-1}$ spectral range is shown in Fig. 4a. The structure of meliphanite consists of three dimensional silicate sheets with multiple linked silica tetrahedra [1,5]. Raman bands are observed at 932, 968, 991, 1016, 1050 and $1095 \mathrm{~cm}^{-1}$ and are assigned to the $\mathrm{SiO}$ stretching vibrations. The Raman bands at 870 and $893 \mathrm{~cm}^{-1}$ may be attributed to hydroxyl deformation modes. Dowty calculated the band positions for the different ideal silicate units. Dowty showed that the $-\mathrm{SiO}_{3}$ units had a unique band position of $1025 \mathrm{~cm}^{-1}$ [17] (see Figs. 2 and 4 of this reference). Dowty

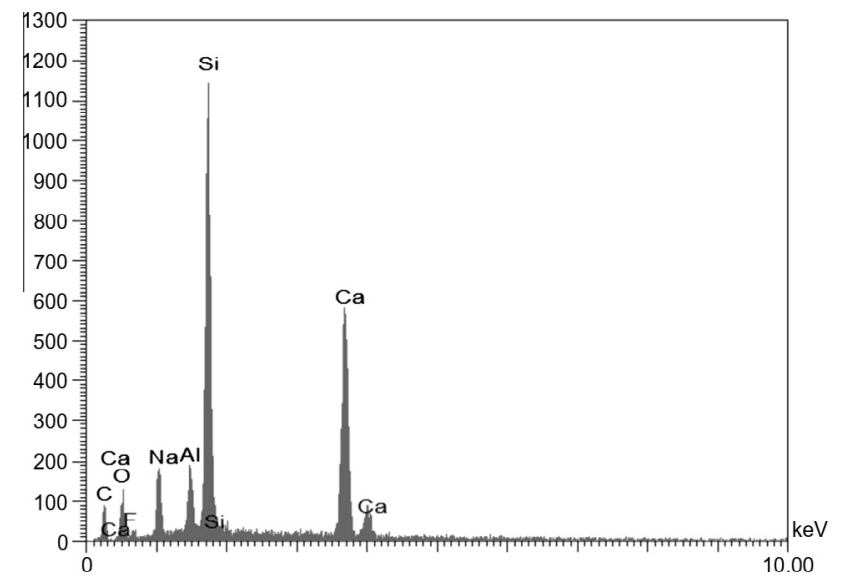

Fig. 2. EDS analysis of meliphanite.
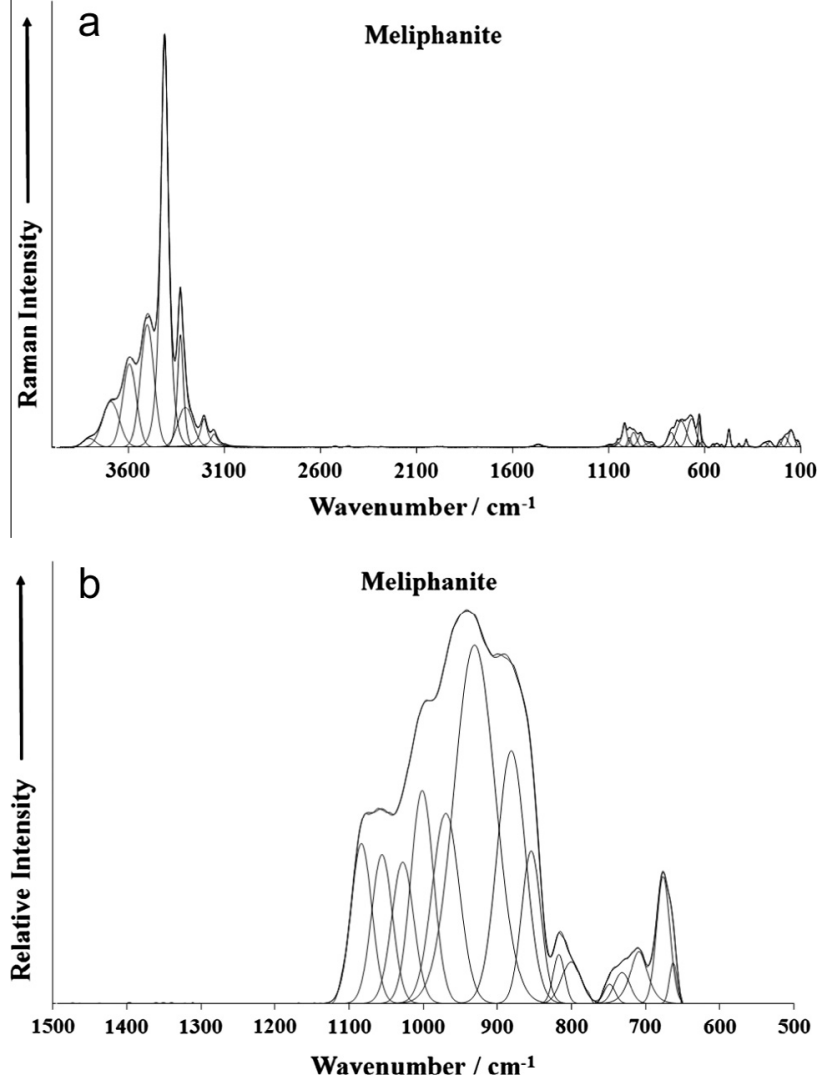

Fig. 3. (a) Raman spectrum of Meliphanite over the $100-4000 \mathrm{~cm}^{-1}$ spectral range and (b) infrared spectrum of Meliphanite over the $500-4000 \mathrm{~cm}^{-1}$ spectral range.
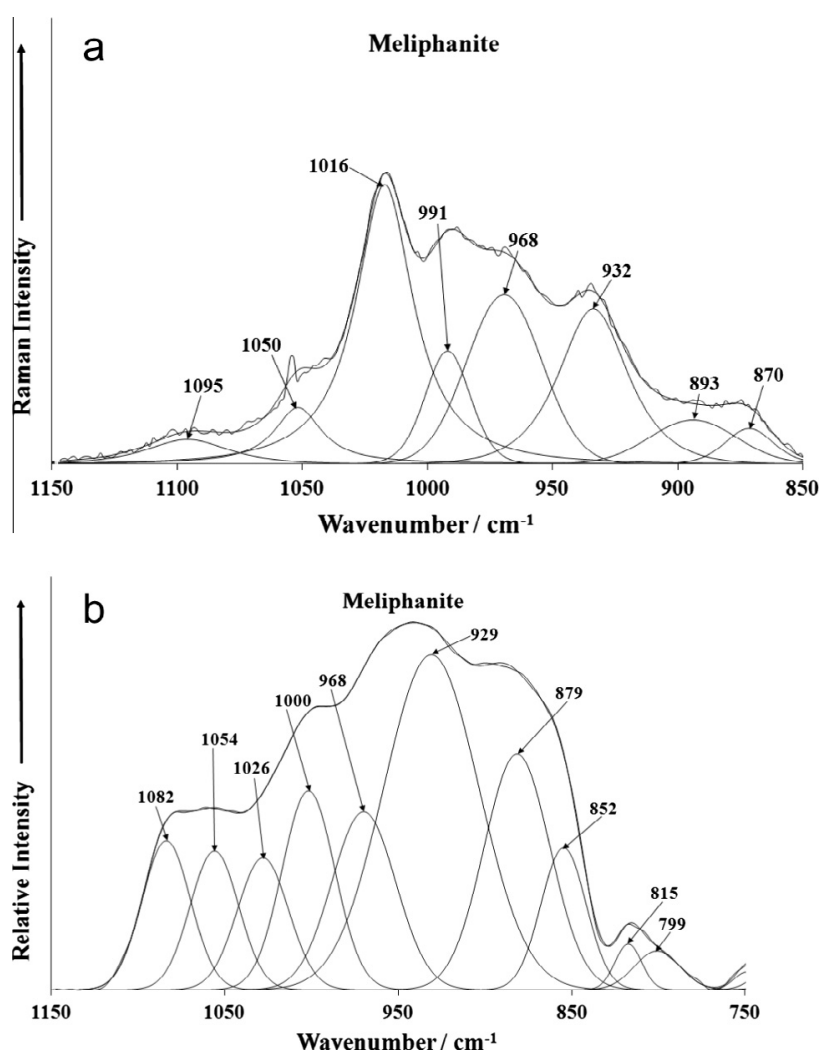

Fig. 4. (a) Raman spectrum of Meliphanite over the $800-1400 \mathrm{~cm}^{-1}$ spectral range and (b) infrared spectrum of Meliphanite over the $500-1300 \mathrm{~cm}^{-1}$ spectral range. 
calculated the Raman spectrum for these types of silicate networks and predicted two bands at around 1040 and $1070 \mathrm{~cm}^{-1}$ with an additional band at around $600 \mathrm{~cm}^{-1}$. In this work we find the Raman bands at 1050 and $1095 \mathrm{~cm}^{-1}$ in agreement with the work of Dowty. In this work we have an additional Raman band at $1016 \mathrm{~cm}^{-1}$. It is suggested that this band is due to $\mathrm{AlOH}$ vibrations. The infrared spectrum over the $750-1150 \mathrm{~cm}^{-1}$ spectral range is reported in Fig. 4b. The infrared spectrum is quite broad and may be resolved into component bands at 799, 815, 852, 879, 929, $968,1000,1026,1054$ and $1082 \mathrm{~cm}^{-1}$. These bands are assigned to $\mathrm{SiO}$ and $\mathrm{AlO}$ stretching vibrations.

The Raman spectrum of meliphanite over the $350-850 \mathrm{~cm}^{-1}$ spectral range is shown in Fig. 5a. The spectrum shows complexity. Intense Raman bands are observed at 472, 625, 666, 721 and $774 \mathrm{~cm}^{-1}$ and are assigned to OSiO and OAlO bending vibrations. Bands of lesser intensity are observed at 382, 421, 510, 534, 555 and $611 \mathrm{~cm}^{-1}$. These bands may also be attributed to the OSiO and OAlO bending vibrational modes. Some of these bands may be assigned to FAlF bending modes. In order to sort out the exact assignment of these bands, it is necessary to undertake theoretical calculations to determine the exact position of the bands. Such work is beyond the scope of this research. The Raman spectrum of meliphanite over the $100-350 \mathrm{~cm}^{-1}$ spectral range is shown in Fig. 5b. Raman bands are found at 113, 147, 180, 207, 258 and $285 \mathrm{~cm}^{-1}$. These bands are simply described as lattice vibrations. The question arises as to where bands that might be assigned to $\mathrm{BeO}$ and $\mathrm{OBeO}$ vibrations. Because of the low atomic mass of $\mathrm{Be}$, these bands are predicted to occur at higher wavenumbers.

The formula of meliphanite is such that there are $\mathrm{OH}$ units involved in the structure $\left[(\mathrm{Ca}, \mathrm{Na})_{2} \mathrm{Be}\left[(\mathrm{Si}, \mathrm{Al})_{2} \mathrm{O}_{6}(\mathrm{~F}, \mathrm{OH})\right]\right.$. With such a formula, it could be expected that there would be spectra observed in the hydroxyl stretching region. This is the case for
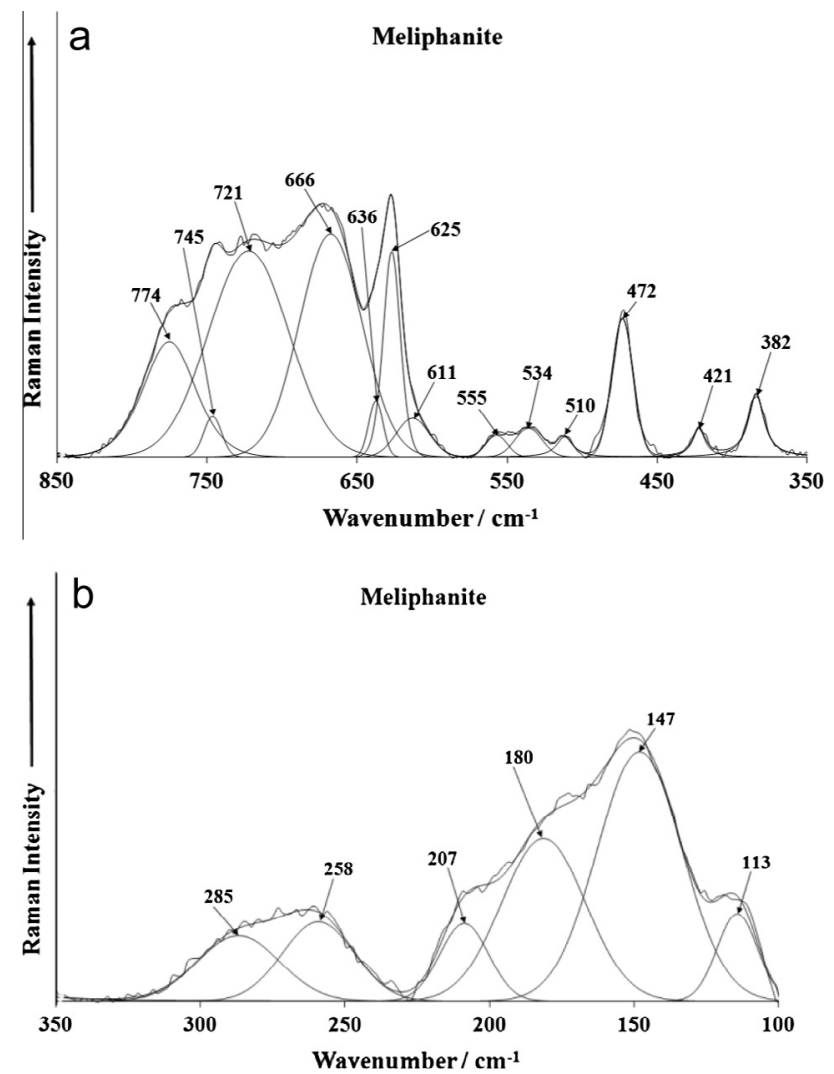

Fig. 5. (a) Raman spectrum of Meliphanite over the $300-800 \mathrm{~cm}^{-1}$ spectral range and (b) Raman spectrum of Meliphanite over the $100-300 \mathrm{~cm}^{-1}$ spectral range.

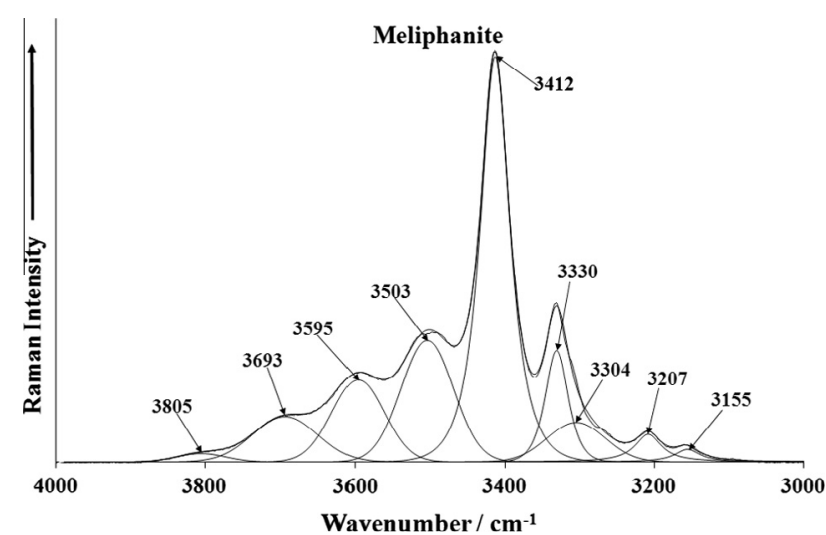

Fig. 6. Raman spectrum of Meliphanite over the $3000-4000 \mathrm{~cm}^{-1}$ spectral range.

the Raman spectrum as may be observed in Fig. 6; however, no intensity in the infrared spectrum was observed. This is somewhat of a conundrum. The Raman spectrum of meliphanite over the $3000-4000 \mathrm{~cm}^{-1}$ spectral range shows a series of Raman bands with different intensities.

The most intense band is observed at $3412 \mathrm{~cm}^{-1}$ and is assigned to the stretching vibration of $\mathrm{OH}$ units. Other Raman bands of lesser intensity are observed at 3155, 3207. Other Raman bands of lesser intensity are observed at $3155,3207,3304,3330 \mathrm{~cm}^{-1}$ on the lower wavenumber side of the $3412 \mathrm{~cm}^{-1}$ band. Raman bands on the higher wavenumber side are noted at 3503, 3595, 3693 and $3805 \mathrm{~cm}^{-1}$. The observation of multiple Raman bands in this spectral region supports the concept of the wide variability of hydrogen bonding of these $\mathrm{OH}$ units. Raman bands are observed at 3155 , $3207,3330,3503,3595$ and $3693 \mathrm{~cm}^{-1}$. It is difficult to assign all these bands simply to the stretching vibrations of the $\mathrm{OH}$ units. It is possible that some of these bands are due to AlF or SiF stretching bands. The higher wavenumber bands may be due to $\mathrm{SiOH}$ stretching vibrations.

\section{Conclusions}

The mineral meliphanite $(\mathrm{Ca}, \mathrm{Na})_{2} \mathrm{Be}\left[(\mathrm{Si}, \mathrm{Al})_{2} \mathrm{O}_{6}(\mathrm{~F}, \mathrm{OH})\right]$ is related to the minerals melitite, leucophanite and gugiaite. Chemical analysis using the EDS technique combined with Raman spectroscopy suggest that the studied sample is an intermediate member of a series between meliphanite and an $\mathrm{OH}$-rich unknown member. $\mathrm{Be}$ is not detected using the EDS technique. Fundamentally the mineral is a type of calcium silicate.

Raman spectroscopy identifies bands in the $3000-4000 \mathrm{~cm}^{-1}$ spectral region. Multiple bands are observed and are assigned to the stretching vibration of the $\mathrm{OH}$ units in the meliphanite structure. The most intense Raman band is found at $3412 \mathrm{~cm}^{-1}$. The observation of a multiplicity of Raman bands supports the concept of a wide variation in the hydrogen bonding of these $\mathrm{OH}$ units.

A series of Raman bands at 932, 968, 991, 1016 and $1050 \mathrm{~cm}^{-1}$ are assigned to the stretching vibrations of the $\mathrm{SiO}$ units. Raman bands at 870 and $893 \mathrm{~cm}^{-1}$ together with the infrared bands at 799 and $815 \mathrm{~cm}^{-1}$ are attributed to hydroxyl deformation modes. Multiple Raman bands are observed in the $350-850 \mathrm{~cm}^{-1}$ spectral region. Raman bands at 625, 636, 666, 721, 745 and 774 are assigned to OSiO bending vibrations. Raman spectroscopy enables the characterization of the vibrational spectrum of meliphanite and may be applied to several related minerals.

\section{Acknowledgements}

The financial and infra-structure support of the Discipline of Nanotechnology and Molecular Science, Science and Engineering 
Faculty of the Queensland University of Technology, is gratefully acknowledged. The Australian Research Council (ARC) is thanked for funding the instrumentation. The authors would like to acknowledge the Center of Microscopy at the Universidade Federal de Minas Gerais (http://www.microscopia.ufmg.br) for providing the equipment and technical support for experiments involving electron microscopy.

\section{Appendix A. Supplementary material}

Supplementary data associated with this article can be found, in the online version, at http://dx.doi.org/10.1016/j.saa.2014.09.018.

\section{References}

[1] A.D. Negro, G. RossI, L. Ungaretti, Acta Cryst. 23 (1967) 260.

[2] S.T. Badalov, Dokl. Akad. (1960) 15-16.

[3] I.V. Bel'kov, A.P. Denisov, Mat. Min. Kol'skogo Pol. 6 (1968) 221-224.

[4] H.I. Jensen, Proc. Linnean Soc. N.S. Wales 32 (1908) 557-626.

[5] J.D. Grice, F.C. Hawthorne, Can. Min. 40 (2002) 971-980.

[6] W.H. Zachariasen, Zeit. Krist. 74 (1930) 226-229.

7] H. Friis, A.A. Finch, C.T. Williams, Phys. Chem. Miner. 38 (2011) 45-57.

[8] M. Fleischer, Am. Miner. 48 (1963) 211-212.
[9] C.L. Knight, M.A. Williamson, R.J. Bodnar, Microbeam Analysis (San Francisco) 24 (1989) 571-573.

[10] I.A. Belitskii, G.A. Golubova, Mater. Geneticheskoi i Eksperimental'noi Min. 7 (1972) 310-323.

[11] F. Pechar, D. Rykl, Casopis pro Min. Geol. 26 (1981) 143-156.

[12] E. Libowitzky, Monatsh. Chem. 130 (1999) 1047-1059.

[13] W. Pilz, Acta Phys. Hung. 61 (1987) 27-30.

14] L. Ancillotti, E.M. Castellucci, M. Becucci, Proc. of SPIE-Int. Soc. Opt. Eng. 5850 (2005) 182-189.

[15] E. Dowty, Phys. Chem. Miner. 14 (1987) 542-552.

[16] E. Dowty, Phys. Chem. Miner. 14 (1987) 122-138.

[17] E. Dowty, Phys. Chem. Miner. 14 (1987) 80-93.

[18] Y. Okada, H. Shibasaki, T. Masuda, Onoda Kenkyu Hokoku 45 (1994) 126-141.

[19] A. Winkler, W. Wieker, Zeit. Chem. 18 (1978) 375-376.

[20] A.E. Zadov, N.V. Chukanov, N.I. Organova, O.V. Kuz'mina, D.I. Belokovskii, M.A Litsarev, V.G. Nechai, F.S. Sokolovskii, Zapiski Vserossiiskogo Miner. Obshchestva 130 (2001) 26-40.

[21] R.L. Frost, Y. Xi, Spectrochim. Acta A117 (2014) 428-433.

[22] R.L. Frost, R. Scholz, A. Lopez, Y. Xi, L.M. Graca, J. Mol. Struct. 1059 (2014) 2026.

[23] R.L. Frost, R. Scholz, A. Lopez, Y. Xi, Raman spectroscopy of the arsenate minerals maxwellite and in comparison with tilasite, Spectrochim. Acta, Part A (2014) (Ahead of Print).

[24] R.L. Frost, A. Lopez, Y. Xi, R. Scholz, A.L. Gandini, A vibrational spectroscopic study of the silicate mineral ardennite-(As), Spectrochim. Acta, Part A (2014) (Ahead of Print).

[25] F. Andersen, S.A. Berge, I. Burvald, Norwegen, Mineralien-Welt 7 (1996) 21 100 